\title{
Climate Change And Dengue Hemorrhagic Fever In Banggai Regency
}

\author{
Erni Yusnita Lalusu ${ }^{1}$, Herawati $^{2}$ \\ Epidemiology and Environment Health Deptartment \\ Public Health Faculty, Tompotika Luwuk University \\ Banggai, Indonesia \\ erniyusnitalalusu@gmail.com
}

\author{
Nasrin Kodim ${ }^{3}$ \\ Epidemiology Department \\ Public Health Faculty, University of Indonesia \\ Jakarta, Indonesia \\ nkodim@ui.ac.id
}

\begin{abstract}
Climate change has caused various social impacts such as changing of ecosystem and increasing tropical diseases i.e Dengue Hemorrhagic Fever (DHF). The tropical area which has high humidity has more potential to breed aedes agypti rather than other areas. The pattern of DHF in the District of Banggai had fluctuated since 2010 and in 2016 it has gradually increased by 15 out of 100,000 populations. The aim of this study is to analyze the correlation between climate change and the incidence of DHF in the District of Banggai. The methods used by this research was ecological studies with a time series approach. Data were obtained from the Health Service and the Statistics Agency in District of Banggai from 2010 to 2015 comprised several variables: the number of DHF incidence, the average of rainfall $(\mathrm{mm})$, level of humidity $(\%)$, the average of temperature $\left({ }^{\circ} \mathrm{C}\right)$, and sunlights $(\%)$. Pearson correlation test (r) is provided to analyze the data. The results show that the humidity of DHF cases, rain intensity one month before and the increasing of both temperature and sunlight in the previous three months get significant values $(\rho<0,05)$. It relates to Butterworth (2016) and Ebi et al (2016) who stated the increasing number of vector and dengue virus is affected to the climate change. In addition, the higher temperature, the more spreaded Aedes aegypti counts. As a result, the government should improve the capacity of surveillance to optimize the treatment and prompt responses used for preventing DHF epidemics.
\end{abstract}

Keywords- Dengue Hemorrhagic Fever; climate change; humidity; rain intensity

\section{INTRODUCTION}

Dengue hemorrhagic fever (DHF) is still a global public health problem [1,2]. DHF is one of arbovirus diseases (diseases transmitted by vector of arthropoda type) which is dangerous enough, with untypical symptoms such as influenza, so that it is much neglected and presents typical symptoms after being in severe conditions [1]. Dengue hemorrhagic fever was first reported at the time of two outbreaks in the Philippines and Thailand in 1943. With the mobility of the population and climate change, especially in the tropics, the disease distribution changes and increases [2].

Banggai Regency is a tropical region along the equator and has summer and rainy seasons in the year. During the last 3 years (2014-2016) climate change is indicated by the increase in humidity, rainfall, and changes in climate patterns every year (BPS) [3-5].
The incidence of DHF in Banggai Regency which initially decreased in 2013-2015 has increased again in 2016 (see table 1) with Case Fatality Rate (CFR) of 10.9\% [6-12]. The number is far above the health ministry's target of $0.83 \%$

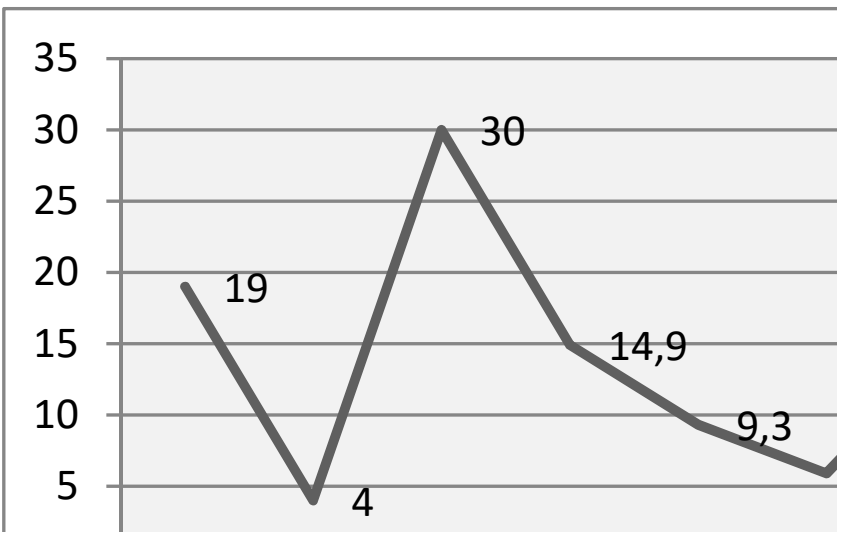

Fig 1. Number of DHF cases (Per 100,000 Population) Banggai Regency 2010-2016.

Mosquito control is the main way to prevent dengue fever. No single type of vaccine has been licensed for the prevention of this disease [1]. In addition to efforts of providing medication and patient care, the other prevention efforts which are also important are monitoring disease and vector development. The surveillance effort is essential to prevent the spread and reduce the incidence of the disease in the next period. To date, illness monitoring and vector development efforts that are reliable and integrated have not been widely applied in many countries, especially in tropical Southeast Asian countries. This is also consistent with the increase in sporadic diseases related to the lack of monitoring efforts [13].

Therefore, researchers will conduct a study of climate change correlation to DHF incidence in Banggai Regency in 2010-2015.

\section{METHOD}

This type of research uses ecological study with time series approach. This study uses secondary data from the Health Service and Central Bureau of Statistics (BPS) of Banggai Regency. Data obtained from Banggai Regency 
Health Service are the Incidence Rate (IR) of DHF from January to December and the mortality rate due to DHF (CFR) during 2010 to 2016. While the data obtained from the Central Bureau of Statistics (BPS) of Banggai Regency include: average rainfall $(\mathrm{mm})$, humidity level $(\%)$, average air temperature $\left({ }^{0} \mathrm{C}\right)$, and sunlight $(\%)$ from January to December in 2010 to 2016. This data has been confirmed at the Meteorology Climatology and Geophysics Agency (BMKG) of Banggai Regency. Data analysis are univariate, bivariate and multivariate. The bivariate analysis used spearman correlation test (r) and time lag in the same month (lag 0), one month earlier (lag 1), in the previous two months (lag 2) and in the previous three months (lag 3) with DHF incidence. To determine the correlation of various climatic variables simultaneously to the occurrence of DHF, then multivariate analysis was done by including all variables that have significant correlation with $\mathrm{p}$-Value $<0.25$. Multivariate analysis using linear regression test will eliminate the variable one by one with $\mathrm{p}$-Value $>0,05$ on each step, to produce an appropriate equation model to predict the occurrence of DHF.

\section{RESULT}

\section{A. Univariate Analyze}

Univariate analysis showed fluctuations in the incidence of DHF and climate change by month from 2010 to 2015.

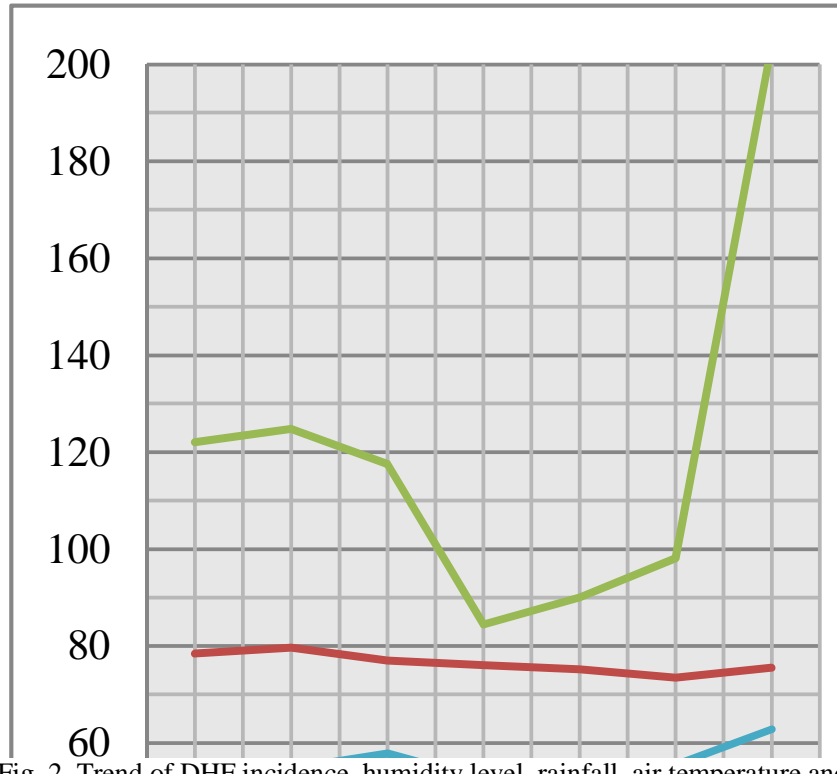

Fig. 2. Trend of DHF incidence, humidity level, rainfall, air temperature and sunlight in Banggai District 2010-2016

The highest incidence of DHF occurs in 2012 with an Incident Rate (IR) of 30 per 100,000 populations. The highest average air humidity in 2011 was $79.6 \%$, the highest rainfall in 2012 was $124.8 \mathrm{~mm}$, the highest temperature in 2010 was $28,18^{\circ} \mathrm{C}$ and the highest sunlight in 2012 was $57.8 \%$ (see picture 2).

In 2016 there was an increase in the Incidence Rate of DHF to 15.3 per 100,000 populations, from 5.9 per 100,000 populations by 2015 . This increase is in line with climate change, where there is an increase in the average humidity level of $2.8 \%$, temperature $2 \%$, sunlight $13.4 \%$ and rainfall doubled from the previous year

\section{B. Bivariate Analyze}

The trend between the increase of DHF incidence and climate change shown in univariate analysis will be further explained in bivariate analysis using Pearson correlation test (see table 1). Climate change has a significant correlation with an increase in the incidence rate of DHF. This correlation is different at each time period.

TABLE I

ANALYSIS OF CLIMATE CHANGE AND DHF INCIDENTS IN BANGGAI REGENCY 2010-2015

\begin{tabular}{|c|c|c|c|c|c|}
\hline \multicolumn{2}{|c|}{ Variabel } & \multicolumn{4}{|c|}{ Lag } \\
\hline & & \multirow{2}{*}{$\frac{\boldsymbol{0}}{1,000}$} & \multirow{2}{*}{$\frac{1}{0,392}$} & \multirow{2}{*}{$\frac{2}{0,497}$} & \multirow{2}{*}{$\frac{3}{0,177}$} \\
\hline Incidence of & $\overline{\mathrm{R}}$ & & & & \\
\hline & p-Value & & 0,001 & $\begin{array}{r}0,000 \\
*\end{array}$ & 0,136 \\
\hline \multirow[t]{2}{*}{ Humidity } & $\mathrm{R}$ & 0,329 & 0,220 & 0,170 & 0,064 \\
\hline & p-Value & $\begin{array}{r}0,005 \\
*\end{array}$ & 0,064 & 0,153 & 0,591 \\
\hline \multirow[t]{2}{*}{ Rainfall } & $\mathrm{R}$ & 0,222 & 0,350 & 0,056 & 0,111 \\
\hline & p-Value & 0,061 & $\begin{array}{r}0.003 \\
*\end{array}$ & 0,637 & 0,355 \\
\hline \multirow[t]{2}{*}{ Temperature } & $\mathrm{R}$ & $-0,110$ & 0,089 & 0,256 & 0,330 \\
\hline & p-Value & 0,359 & 0,457 & $\begin{array}{r}0,030 \\
*\end{array}$ & $\begin{array}{r}0,005 \\
*\end{array}$ \\
\hline \multirow[t]{2}{*}{ Sunlight } & $\mathrm{R}$ & $-0,178$ & $-0,003$ & 0,060 & 0,250 \\
\hline & p-Value & 0,135 & 0,980 & 0,614 & $\begin{array}{r}0,034 \\
*\end{array}$ \\
\hline
\end{tabular}

Table 1 shows: Humidity levels in the same month significantly correlated with DHF incidence with $r=0.329$ and $\mathrm{p}$-Value $=0.005(\mathrm{p}<0.05)$ indicating moderate correlation. Whereas, the humidity level before the DHF incidence did not show a significant correlation; the rainfall that occurred one month before the DHF incidence (lag 1) indicates the value of $r=0.350$ (moderate correlation) with $\mathrm{p}$ Value $=0.003(\mathrm{p}<0.05)$. While rainfall at the same time did not show significant correlation to DHF incidence; Average air temperatures at 2 months and 3 months before the incidence of DHF showed significant correlation $(p<0.05)$ compared with air temperature at the same time as well as at 1 month before the incidents of DHF; and sun exposure in the previous 3 months showed a significant correlation $(p<0.05)$ to the incidence of DHF compared with at the time of the incident or 2 months earlier.

\section{Multivariat Analyze}

Based on Table 1, there are several variables that are significantly related to DHF incidence. Multivariate analysis is needed to produce a significant correlation model simultaneously to the incidence of DHF. Table 2 shows three models of significant equations for predicting the incidence of DHF. 
TABLE II.

MODEL SUMMARY

\begin{tabular}{|c|c|c|c|c|}
\hline Model & $\mathbf{R}$ & R Square & $\begin{array}{l}\text { Adjusted R } \\
\text { Square }\end{array}$ & $\begin{array}{l}\text { Std. error of the } \\
\text { Estimate }\end{array}$ \\
\hline 1 & $0,497^{\mathrm{a}}$ & 0,247 & 0,236 & 3,729 \\
\hline 2 & $0,576^{\mathrm{b}}$ & 0,331 & 0,312 & 3,539 \\
\hline 3 & $0,626^{\mathrm{c}}$ & 0,392 & 0,365 & 3,399 \\
\hline
\end{tabular}

'Predictors: (Constant), DBD lag2, Suhulag2, Hujanlag1

Various predictor variables in model 3 can explain the incidence of DHF by $39 \%$ with a strong and significant correlation. The regression equation shown by this model has the highest $\mathrm{R}$ and $\mathrm{R}$ squares value with the smallest statistical error standard ( $p$-Value $<0.05$ ). See table 3.

TABLE III. ANOVA

\begin{tabular}{|c|c|c|c|c|c|}
\hline Model & Sum of Square & Df & $\begin{array}{l}\text { Mean } \\
\text { Square }\end{array}$ & $\mathbf{F}$ & Sig. \\
\hline 1 Regression & 319,002 & 1 & 319,002 & 22,935 & $0,000^{\mathrm{a}}$ \\
\hline Residual & 973,609 & 70 & 13,909 & & \\
\hline Total & 1292,611 & 71 & & & \\
\hline 2 Regression & 428,352 & 2 & 214,176 & 17,099 & $0,000^{\mathrm{b}}$ \\
\hline Residual & 864,259 & 69 & 12,525 & & \\
\hline Total & 1292,611 & 71 & & & \\
\hline 3 Regression & 506,870 & 3 & 168,957 & 14,622 & $0,000^{c}$ \\
\hline Residual & 785,741 & 68 & 11,555 & & \\
\hline Total & 1292,611 & 71 & & & \\
\hline
\end{tabular}

Thus, equation model that can predict the incidence of DHF is obtained, with the involvement of predictor variables, namely: the incidence of DHF and the average temperature in the previous 2 months to the incidence of DHF and rainfall of one month earlier.

TABLE IV.

COEFFICIENT

\begin{tabular}{|c|c|c|c|c|c|}
\hline \multirow{2}{*}{ Model } & \multicolumn{2}{|c|}{$\begin{array}{c}\text { Unstandardize } \\
\text { Coeffients }\end{array}$} & \multirow{2}{*}{$\begin{array}{c}\begin{array}{c}\text { Standardize } \\
\text { Coefficients }\end{array} \\
\text { Beta }\end{array}$} & \multirow{2}{*}{$\mathbf{T}$} & \multirow{2}{*}{ Sig. } \\
\hline & B & $\begin{array}{c}\text { Std. } \\
\text { Error }\end{array}$ & & & \\
\hline (Constant) & $-31,528$ & 12,419 & & $-2,629$ & 0,011 \\
\hline $\begin{array}{l}\text { Incidence of } \\
\text { DHF lag2 }\end{array}$ & 0,483 & 0,096 & 0,481 & 5,026 & 0,000 \\
\hline $\begin{array}{l}\text { Temperature } \\
\text { lag2 }\end{array}$ & 1,143 & 0,431 & 0,254 & 2,650 & 0,010 \\
\hline Rainfall lag1 & 0,014 & 0,005 & 0,251 & 2,607 & 0,011 \\
\hline
\end{tabular}

Based on table 4 above, we can formulate the equation model to predict the occurrence of DHF as follows:

$$
\begin{gathered}
\operatorname{DHF}(Y)=-31,528+0,483(\text { DHFlag } 2)+1,143(\text { Temperature } \\
\text { lag } 2)+0,014(\text { Rainfall lag } 1)
\end{gathered}
$$

Equation (1) shows that:

- Any 1 DHF increment in the previous two months will increase the current DHF case by 0.438 from the constant value, assuming another variable is in constant condition.
- If the previous two months' air temperature was normal and the previous month's rainfall was at normal intensity there will be no increase in DHF cases in the current period. Conversely, if the air temperature and rainfall during these periods increases with the high incidence of DHF, there will be an increase in the following cases.

\section{DISCUSSION}

The tropics have high temperatures and humidity as well as the potential to breed aedes agypti mosquitoes [1]. Banggai Regency is a tropical region located astronomically between 003 '- 2020' South Latitude and 122023 '- 1240 20' East Longitude and passed by the equator. Climatic conditions of Banggai regency are currently undergoing changes, as indicated by the increase in temperature, rainfall, humidity, and solar exposure as shown in Picture 2. Wu et al., found with $1{ }^{0} \mathrm{C}$ increase of monthly average of temperatures, the total population at risk for dengue fever transmission would increase by 1,95 times [14].

In this study, there was a significant correlation between DHF and the temperature of the previous two months. Temperature is one of the climatic elements that affect the population increase and the ability of DHF vector. Aedes aegypti larvae eggs hatch $98 \%$ at a temperature of $24-25^{\circ} \mathrm{C}$, but it declined after the increase in temperature. After hatching, the larvae then develop rapidly at a temperature of $30-35^{\circ} \mathrm{C}$ and most of it develops into female mosquitoes. On the contrary at low temperatures 24-25 there is no difference in the number of female and male larvae. The body size of Aedes Aegypti in larvae which maintained at constant temperature is greater than that maintained at temperatures below $24^{\circ} \mathrm{C}-30^{\circ} \mathrm{C}$ [15].

Rainfall is associated with the number of mosquito breeding places. In this study, the incidence of dengue has a correlation with rainfall of the previous month. The study, conducted by Paploski et al 2015, shows rainwater channels functioning as larvae development sites as well as adult mosquito breeds [16]. Rainfall that occurred one month before the DHF incidence plays a role in multiply the mosquito larvae breeding place and is very suitable for the development of mosquitoes into adult stage. The predictive model of presence of aedes agypti mosquitoes conducted by Wilke et al in Brazil's piquery park in 2016 also shows that rainfall in the previous month had an association to the presence of the DHF vector [17].

Bivariate analysis in this study also showed a significant correlation between the humidity and the incidence of DHF. Widyorini et al in his research entitled Dengue Hemorrhagic Fever (DHF) Cases in Semarang City are Related to Air Temperature, Humidity, and Rainfall in 2016 shows that high humidity and rainfall significantly increase the incidence of DHF [18].

Humid conditions are an investment from the occurrence of rain in the previous month. The results of Qureshi et al's study showed that humid conditions were significant in postrain $(p=0.024)[19]$. The tropics have high humidity and the 
potential to breed aedes agypti mosquitoes [13]. After sucking blood, Aedes aegypti female mosquitoes then produce eggs. Eggs that have been laid, can last for a very long time [20-21]. If exposed to water or placed in a watery place, the eggs will hatch into larvae (Clements). This makes the control of dengue virus mosquitoes very difficult. Eggs of aedes agypti will shrink and be damaged in non-humid or dry conditions [21].

Multivariate analysis in this study showed two months temperature and rainfall on one month before the incidents of DHF together have a significant postitive correlation to the incidence of DHF. In Banggai Regency, in 2015, the incidence of DHF increased in July with peak cases occurring in August. The air temperature in the previous two months ranged from 22.6 to $32.4 \mathrm{C}$. The temperature in this month is quite high compared to the previous period. High temperatures lead to increased evaporation which in turn makes rainfall even higher and occurs over a long period of time. From May to July there was a substantial increase in rainfall of $267.2 \mathrm{~mm}^{3}$ for an average of 23 days. This condition led to an increase in humidity to $78 \%$ in June making it particularly suitable for growth and increased DHF vector populations over the past few months. The accumulated rainfall and average monthly temperature for the collection month and previous month were used to explain climate-related abundance drivers for the six month abundant species [17]

The predictive model of presence of aedes agypti mosquitoes conducted by Wilke et al in the Brazilian piquery park in 2016 shows that precipitation in the previous month had an association to the presence of the DHF vector [17]. Rain has a correlation with the incidence of DHF. This is because the rain affects the development of the aedes agypti mosquito as the vector of this disease. Rain can increase the humidity that will support the growth of mosquitoes.

Climate change raises various social impacts such as changes in ecosystems and increases in tropical diseases such as Dengue Haemorrhagic Fever (DHF) [22]. Tabachnick et al, in his study "Challenges in predicting climate and environmental effects on vector-borne disease episystems in a changing world" shows that climate change can affect the epidemiology of disease carried by vectors. Climate change will affect the life cycle and life history of arthropod vectors, resulting in changes in vector distribution and alteration of arthropod ability to transmit DHF disease [23].

The predicted model of increasing the DHF incidence which associated with climate change in research is helpful in understanding the dynamics of the mosquito population. It can be used as a reference in planning prevention and controlling DHF incidence through vector control. It can be used as a reference in planning prevention and control of dengue fever through vector control events. The control interventions can be adjusted according to time-based climate change to be more effective and efficient. To support this, it is hoped that the government in this case the Banggai Regency Health Service will increase the capacity of surveillance to be more integrated with various related sectors. In addition, there needs to be continuous dissemination of information to all parties, both stakeholders and the community, as a unity in the implementation of the surveillance program.

\section{CONCLUSION}

The results of this study indicate a significant correlation between climate change and the incidence of DHF. Climate elements include temperature, rainfall, humidity and radiation of the sun, and the timing of each variable is also important to be concerned. Nevertheless, based on various research results, the incidence of DHF is not only influenced by climate, but also related to geography and demographic factors. Furthermore, it is necessary to study the effect of these factors on the occurrence of DHF. For health workers who deal with DHF problems, in order to develop an integrative surveillance model, so that all information needed in the effort to overcome DHF can be collected and produce good information for decision making.

\section{REFERENCES}

[1] Mood, B.S., Mardani, M. Dengue: A re-emerging disease (2017) Archives of Clinical Infectious Diseases, 12 (1), art. no. e27970, . DOI: 10.5812/archcid. 27970

[2] Messina, J.P., Brady, O.J., Scott, T.W., Zou, C., Pigott, D.M., Duda K.A., Bhatt, S., Katzelnick, L., Howes, R.E., Battle, K.E., Simmons, C.P., Hay, S.I. Global spread of dengue virus types: Mapping the 70 year history (2014) Trends in Microbiology, 22 (3), pp. 138-146. Cited 125 times. DOI: 10.1016/j.tim.2013.12.011

[3] Banggai Regency in Figures, BPS-Statistics of Banggai Regency, 2015

[4] Banggai Regency in Figures, BPS-Statistics of Banggai Regency, 2016

[5] Banggai Regency in Figures, BPS-Statistics of Banggai Regency, 2017

[6] Profil Kesehatan Kabupaten Banggai, Health Service of Banggai Regency, 2010

[7] Profil Kesehatan Kabupaten Banggai, Health Service of Banggai Regency, 2011

[8] Profil Kesehatan Kabupaten Banggai, Health Service of Banggai Regency, 2012

[9] Profil Kesehatan Kabupaten Banggai, Health Service of Banggai Regency, 2013

[10] Profil Kesehatan Kabupaten Banggai, Health Service of Banggai Regency, 2014

[11] Profil Kesehatan Kabupaten Banggai, Health Service of Banggai Regency, 2015

[12] Profil Kesehatan Kabupaten Banggai, Health Service of Banggai Regency, 2016

[13] Gonzalez, J.-P., Souris, M., Valdivia-Granda, W. Global spread of hemorrhagic fever viruses: Predicting pandemics (2018) Methods in Molecular Biology, 1604, pp. 3-31. DOI: 10.1007/978-1-4939-6981-4_1

[14] Wu, P.-C., Lay, J.-G., Guo, H.-R., Lin, C.-Y., Lung, S.-C., Su, H.-J. Higher temperature and urbanization affect the spatial patterns of dengue fever transmission in subtropical Taiwan (2009) Science of the Total Environment, 407 (7), pp. 2224-2233. Cited 110 times. DOI: 10.1016/j.scitotenv.2008.11.034

[15] Mohammed, A., Chadee, D.D., Effects of different temperature regiments on the development og aedes aegypti mosquitoes, Acta Tropica 119 (2011) 38-43

[16] Paploski, I.A.D., Rodrigues, M.S., Mugabe, V.A., Kikuti, M., Tavares, A.S., Reis, M.G., Kitron, U., Ribeiro, G.S. Storm drains as larval development and adult resting sites for Aedes aegypti and Aedes albopictus in Salvador, Brazil (2016) Parasites and Vectors, 9 (1), art. no. 419 , . Cited 5 times. DOI: 10.1186/s13071-016-1705-0 
[17] Wilke, A.B.B., Medeiros-Sousa, A.R., Ceretti-Junior, W., Marrelli, M.T. Mosquito populations dynamics associated with climate variations (2017) Acta Tropica, 166, 10.1016/j.actatropica.2016.10.025

[18] Widyorini, Prasti, Shafrin, Kintan Arifa; Wahyuningsih, Nur Endah; Murwani, Retno; SuhartonoDengue Hemorrhagic Fever (DHF) Cases in Semarang City are Related to Air Temperature, Humidity, and Rainfall, Advanced Science Letters, Volume 23, Number 4, April 2017, pp. 3283-3287(5)

[19] Qureshi, E.M.A., Tabinda, A.B., Vehra, S. The distribution of Aedes aegypti (Diptera, culicidae) in eight selected parks of Lahore, using oviposition traps during rainy season (2017) Journal of the Pakistan Medical Association, 67 (10), pp. 1493-1497

[20] Rezende, G.L., Martins, A.J., Gentile, C., Farnesi, L.C., PelajoMachado, M., Peixoto, A.A., Valle, D. Embryonic desiccation resistance in Aedes aegypti: Presumptive role of the chitinized Serosal Cuticle (2008) BMC Developmental Biology, 8, art. no. 82, . Cited 60 times. DOI: $10.1186 / 1471-213 X-8-82$

[21] Joceline Lega Heidi E. Brown Roberto Barrera Aedes aegypti (Diptera: Culicidae) Abundance Model Improved With Relative Humidity and Precipitation-Driven Egg Hatching, Journal of Medical Entomology, Volume 54, Issue 5, 1 September 2017, Pages 1375-1384

[22] Simoy, M.I., Simoy, M.V., Canziani, G.A. The effect of temperature on the population dynamics of Aedes aegypti (2015) Ecological Modelling, 314, pp. 100-110. Cited 7 times. DOI: 10.1016/j.ecolmodel.2015.07.007

[23] Tabachnick, W.J. Challenges in predicting climate and environmental effects on vector-borne disease episystems in a changing world (2010) Journal of Experimental Biology, 213 (6), pp. 946-954. Cited 134 times. DOI: $10.1242 /$ jeb.037564. 